Relatorio

\title{
PAISAXE E IDENTIDADE NO DISCURSO GALEGUISTA
}

Caroline Domingues

Université Blaise-Pascal de Clermont-Ferrand 

De Manuel Murguía a Castelao, a paisaxe de Galicia representa na identidade galega un elemento clave para identificar e diferenciar. Identifícase cos países celtas e o norte de Portugal; diferénciase coa seca Meseta castelá. Os teóricos do galeguismo trataron o tema da paisaxe alén da súa dimensión puramente xeográfica, como un elemento central da personalidade galega, elemento a partir do que se desenvolveron unha estética, unha cultura, unha organización política, e mesmo un carácter galego identificable e único. Segundo eles, a paisaxe é civilización, fonte de poesía, de literatura e de expresión artística.

O propósito deste traballo é analizar este tema esencial da galeguidade co apoio de dúas obras clave do pensamento nacionalista galego: Teoría do nacionalismo galego, de Vicente Risco, e Sempre en Galiza, de Castelao, pero incorporarei tamén ensaios e artigos destes dous intelectuais e outras achegas de diferentes personalidades do galeguismo.

Veremos que a paisaxe galega, lugar das orixes, se converte en «templo» da memoria ata ser, en Castelao, un xardín de Edén, que aspira a recobrar a idade de ouro das súas orixes. Examinaremos as dimensións cultural e estética da paisaxe, berce da creación artística. Analizaremos como a paisaxe representa un dato imprescindible na construción dunha identidade persoal, artística e colectiva e como, no caso galego, participa na definición da identidade e lle serve de fundamento á ideoloxía política.

Todas as preguntas verbo da paisaxe coinciden para definilo como obxecto e, asemade, como suxeito. A paisaxe revélase, en efecto, «nunha experiencia en que suxeito e obxecto son inseparables», precisa Michel Collot (1995, p. 211). Fálase, ás veces, de diálogo entre o sitio natural e a intervención humana, xa que a ordenación do terreo traduce, de maneira singular, a reciprocidade entre o cultural e o natural. Segundo o xeógrafo americano John Brinckerhoff Jackson (2003, p. 11-12), a paisaxe é «unha sucesión de pegadas, de marcas que se sobrepoñen no chan. Neste sentido, é como unha obra de arte; a terra, o solo, a natu- 
reza son os materiais usados e organizados polos homes segundo valores culturais. Estes son diferentes no tempo e no espazo» ${ }^{1}$. Para este mesmo autor, a paisaxe é «a encarnación do espírito dunha cultura, dos seus valores e aspiracións [...]. Neste sentido, a paisaxe é como un traxe de humanidade posto no solo. A actividade humana inscríbese no solo e transfórmao» (Jackson, 2003, p. 18-19). Así, a paisaxe é unha marca cultural da natureza. É, asemade, un espazo natural, cultural e social. Trátase, segundo a definición de Anne Sgard, da manifestación sensitiva da inscrición dunha sociedade no seu marco de vida (Sgard, 1997). A paisaxe desempeña un papel de «mediadora» na relación entre os habitantes e o territorio, e aparece como un dato esencial do vínculo afectivo e estético que o habitante mantén con ese mesmo territorio e que participa da súa apropiación. Ao evocar Andalucía, Yves Luginbühl precisa que só se lles chama paisaxes aos espazos que presentan unha capacidade de seren idealizados ou de procuraren o benestar; as inmensas parcelas de cereais non constitúen unha paisaxe para a maioría dos habitantes, que consideran estas chairas só como un espazo de traballo (Collot, 1995, p. 323). A ocupación tradicional do territorio en Galicia e a súa transformación en paisaxe cultivada como un xardín, e non para o proveito dunha industria agrícola, ofrece así a visión dun intercambio constante e permanente e dunha comuñón perenne entre home e natureza.

Para os investigadores en Etnoxeografía, o territorio non é só «un fragmento de espazo que o grupo se apropia [...], é tamén o punto de fixación no que arraigan os valores e no que se confirma a identidade dunha comunidade. Esta identidade confúndese co territorio, terra nutricia material e espiritual [...]. Hai así unha relación esencial entre o territorio recoñecido como tal por un grupo e a identidade que se constrúe e que o constrúe» (Collignon, 1999, p. 93). No caso das sociedades agrarias fortemente arraigadas no tempo e no espazo, como Galicia, a paisaxe confúndese co espazo de produción e co espazo vivido de maneira cotiá (Bertrand, 1995, p. 103-104). En Galicia, a paisaxe pon en escena a historia cotiá; é o teatro do ordinario. Esta combinación das escalas temporais, espaciais e sociais converten a paisaxe nun dos soportes privilexiados da identidade colectiva (Sgard, 1997). Na procura da identidade, a

\footnotetext{
${ }^{1}$ Toda paisaxe, en certa maneira, é relativa a un proxecto, aínda que este non sexa "consciente», aínda que sexa o reflexo inconsciente da organización dunha vida social (Jackson, 2003, p. 17-18).
} 
paisaxe desempeña un papel fundamental: «Visualiza o patrimonio no que se apoia a identidade: patrimonio natural ou humano, antigo ou actual; acompaña as prácticas cotiás ou excepcionais e, especialmente, as prácticas simbólicas, festivas ou rituais, tamén fundadoras de identidade; pon en escena a inscrición dunha sociedade no seu territorio», explica Anne Sgard ${ }^{2}$. Agora ben, segundo esta autora, "paisaxe e territorio teñen en común unha dimensión fundadora, o tempo: o territorio inscríbese na duración e a paisaxe fálalle á memoria e bota as súas raíces no tempo» (Sgard, 1997). "Nesta memoria [precisa Bernard Bourgeois], inscríbese a civilización nas súas prácticas máis materiais» (Bourgeois, 1982, p. 208). En efecto, na propia carne da paisaxe están impresos e perduran todos os estigmas do pasado (Dagognet, 1982, p. 40).

É o caso do castro galego ${ }^{3}$, elemento máis característico da paisaxe e pegada celta inscrita no territorio. $\mathrm{O}$ castro converteuse en obxecto de estudo da historia reivindicativa que nacía no século XIX en Galicia, explica a historiadora Beatriz Díaz Santana (2002, p. 53). Foi dotado non só dun valor histórico senón tamén ideolóxico. Os primeiros historiadores románticos analizaron as características diferenciais da paisaxe galega: "A estrutura atomizada da propiedade [precisa Beatriz Díaz Santana] foi vinculada coas comunidades celtas pre-romanas» (Díaz Santana, 2002, p. 133-134).

Ademais, a Arqueoloxía da paisaxe establece que o campesiñado, presente desde a Idade do Ferro, ten configurado un tipo específico de ocupación do espazo e, sobre todo, de paisaxe (Díaz Santana, 2002, p. 112-113). Para o historiador Manuel Murguía (1833-1923), o campesiñado sintetizaba a esencia dos antepasados celtas, xa que nel se mantiñan vivas as tradicións e a paisaxe. Esta opinión foi compartida por Vicente Risco (1884-1963), que define a identidade galega pola súa poboación de campesiños e de mariñeiros, e pola súa organización natural, que é a parroquia, comunidade esencialmente agraria e rural. «Os labregos eiquí son todo, non somentes por compoñel-a imensa maor parte da poboación, senon por seren os que nos manteñen a todos» (Risco, 2000, p.

\footnotetext{
2 «A paisaxe [conclúe Anne Sgard] está sentida como unha forma apropiada de transcrición da identidade territorial e constitúe un dos principais temas do discurso identitario en todo caso nas sociedades rurais»; (Sgard, 1997).

${ }^{3}$ Os castros son organizacións urbanas. Apareceron no século X a. de C. Tratábase de instalacións fortificadas situadas en outeiros estratéxicos para controlar o camiño do metal.
} 
21-22). Castelao (1886-1950), pola súa parte, define o ruralismo como forma de instalación natural dos galegos en oposición clara coa urbana: «a poboación está distribuída en natural desorde, coma nos países celtas, i en evidente contraste cos módulos de agrupamento social en Castela e demais rexións hespañolas» (Rodríguez Castelao, 2000, p. 169). Así mesmo, Manuel Murguía afirmaba que esta paisaxe dividida das comunidades campesiñas galegas era idéntica no pasado. $\mathrm{O}$ vínculo entre pasado e presente reflectíase nunha mesma paisaxe rural. Durante o século XIX, o campesiñado galego representou a identidade nacional nacida da cultura castrexa (Díaz Santana, 2002, p. 137). Así naceu a idea de que aquel asentamento castrexo estaba ao principio da ocupación do espazo galego e da distribución administrativa das súas parroquias, tan características da paisaxe (Díaz Santana, 2002, p. 124-126). Para o historiador Pereira Menaut, unha mesma paisaxe equivale a unha mesma identidade cultural, xa que, segundo este autor, a paisaxe é a consecuencia dun proceso histórico que o explica e lle dá unha identidade. Este feito diferencial, que existiría, segundo Pereira Menaut, desde a Protohistoria, marca e determina a identidade nacional galega (Díaz Santana, 2002, p. 130).

Esta terra galega, para Castelao, pérdese nas orixes dos tempos e confúndese así co solo orixinario sobre o que apareceron os primeiros homes: «Non esquezamos que Galiza era unha insua de rocas ígneas criadas polo lume astral, e que xurdía, outa e forte, dos mares formativos, en cuio caos aínda xacía o que hoxe chamamos Hespaña» (Castelao, 2000, p. 89). Desta terra, xorde unha enerxía incoercible xeradora de inmortalidade. É froito do encontro entre o home e a paisaxe e, en verbas do xeógrafo e escritor Ramón Otero Pedrayo (1888-1976), «nun entrar da paisaxe no home e do home na paisaxe, creouse a vida eterna de Galiza» (Castelao, 2000, p. 335).

$\mathrm{Na}$ encrucillada do tempo e da identidade, Galicia, a súa terra e as súas paisaxes son fieis ao "fondo primitivo» a partir do que se crearon, como se a paisaxe galega invitase a recobrar o estado inicial do mundo. A paisaxe, segundo Castelao, é o froito da natureza e dunha historia que se remonta, en Galicia, á Idade Prehistórica, cando as formas actuais de Castela -mesmo a paisaxe- naceron nas últimas etapas da Reconquista (Castelao, 2000, p. 347-349). «Maxinemos unha resurreición dos mortos de fai mil [di Castelao]: un galego recoñecería a súa terra; un castelán non sabería decir onde estaba» (Rodríguez Castelao, 2000, p. 351). 
Vemos aquí a vontade de insistir na inmutabilidade da paisaxe galega, unha paisaxe inscrita nunha civilización que ten as súas orixes nun encontro inmemorial entre o home e mais a Terra atravesada de universalidade: «dende a máis pequena fiestra pode contemplarse a inmensidade do ceo coma dende a máis pequena terra se pode comprender a grandeza do mundo» (Rodríguez Castelao, 2000, p. 324).

Esta terra, que compara a «unha inmensa esmeralda engarzada no extremo da cordilleira cantábrica» (Rodríguez Castelao, 2000, p. 543), diferénciase ou mesmo se opón ao resto de España pola súa beleza; así, dúas veces en Sempre en Galiza, Castelao declara: «Eu sei que tódolos galegos estamos orgullosos de ser fillos da Terra máis fremosa de Hespaña e cicais a máis fremosa do mundo» (Rodríguez Castelao, 2000, p. 306). Fronte a esta terra galega fecunda, rica en paisaxes verdosas, están as "chairas desertas, resecas e calvas da Meseta» (Rodríguez Castelao, 2000, p. 348). A poeta Rosalía de Castro (1837-1885), no prólogo dos seus Cantares gallegos, eleva as paisaxes de Galicia á categoría de ideais, de modelos culturais e estéticos. E, despois de estigmatizar os da Mancha ou de Estremadura, de Alacante e mais de Murcia, feitos de campos monótonos, describe as xoias da paisaxe galega, estes elementos do cotián que fan do seu país «un dos máis encantadores da terra». A hostilidade de Rosalía de Castro é tanto cara aos «castellanos» -manifestada por exemplo no poema «Castellanos de Castilla»- como contra unha paisaxe que non entende.

No medio do deserto castelán, as cidades, caos urbano e axitado, opóñense ao campo galego, único depositario das esencias eternas: un «inxénito ruralismo» fronte a unha "retrasada urbanidade», segundo Castelao. O discurso de Castelao ten así acentos «rousseauniáns». Trátase, segundo a análise de Ramón Maiz, da dimensión do ruralismo como paisaxe: o campo idealizado -como unha Arcadia- representa un antídoto contra a axitación da cidade. De aí o perigo dun poder castelán que imporía as súas decisións na paisaxe; no seu percorrido polo territorio galego, Castelao constata o que "para nós, siñificou e siñifica o Estado hespañol nascido en Castela» (Rodríguez Castelao, 2000, p. 347) e fala de montañas antes poboadas de árbores e logo totalmente «calvas» e de que sofren unha «maldita esterilidade» a causa das decisións de Castela, cando poderían ter constituído, pola contra, «a nosa fonte principal de riqueza». "Nestes montes [resume o teórico], está presente o ideal arrasador de Castela, nemiga 
dos albres e dos paxaros» (Castelao, 2000, p. 347). Este poder nefasto, esta man castelá diabólica veu a empobrecer e desecar a paisaxe galega: «Non é pois, necesario saír de Galiza para ver a Castela ou para comprender o mal que esta causou a Hespaña no proceso de unificación nacional», afirma Castelao (Castelao, 2000, p. 347). Así e todo, asegura con tranquilidade que: «O que non podía morrer era a Terra -siño permanente da nación- porque por moito poder que o Estado centralista tivese, sempre resultaría impotente para convertir o noso territorio en planura castelán» (Castelao, 2000, p. 91), exemplo, para Castelao, de fealdade e de infertilidade. Xa que logo, propón que, «se a unificación fose comenente, non sería máis cordo galeguizar a Castela que castelanizar a Galiza?» (Castelao, 2000, p. 91).

Pero alén do aspecto concreto da paisaxe, o cariño que teñen os homes por ela mostra unha vez máis o abismo que separa os galegos dos casteláns: este cariño e fascinación fai que se opoñan os galegos contemplativos, os que lle renden culto á natureza, aos casteláns, que prefiren unha relixión descarnada e baldeira de contidos terrestres. «Se quixeramos diferenciar o esprito galego do esprito castelán diríamos que están representados nas lendas de Don Ero e do padre Navarrete. Nós somos o monxe que ficou en éistasis polo canto dun paxaro; eles son o monxe que mandou calar aos paxaros para entregarse á meditación», resume Castelao (Castelao, 2000, p. 439). De aí o seu desexo: «Como lle queremos á Terra! Eu de min sei decirvos que se dispois de morto tivese que voar máis alá das estrelas visibles, para ir a un ceo tan lonxano da Terra, que nunca máis poidera vela, de boa gana renunciaría á inmortalidade para rematar a miña vida debaixo dunha laxe e convertirme en herbas ventureiras» (Castelao, 2000, p. 92).

Así e todo, cada galego ten unha forza que o empurra a deixar a súa terra. Pero, neste caso, tamén a diferenza cos seus veciños é grande: «Os casteláns sofren miseria i escravitude por non aleixárense da familia, dos colchóns, dos pucheiros, dos barreñóns, das tixolas e do gato [...]. Os casteláns non se moven do chan nativo o vanse del para sempre. Non hai dúbida de que a emigración galega revela unha diferencia de carácter cando se compara co sedentarismo castelán. Hai unha forza que nos empurra cara o mundo e outra que nos xungue á terra nativa, pois se os camiños nos tentan a camiñar é porque deixamos unha luz acesa sobor da casa en que fomos nados, e alí nos agarda ao fin da vida. 
Andar, andar, andar, e no remate dos traballos devolverlle á Terra o corpo que ela nos emprestou» (Castelao, 2000, p. 297-298).

Este regreso cara ao chan maternal está inscrito, segundo Castelao, en cada ser galego, como se home e terra fosen un: un mesmo espírito expresado na saudade -sufrimento por estar afastado- e un mesmo corpo arraigado para sempre no chan de Galicia.

Evocando o amor dos galegos pola natureza, Castelao explica que a base do ser galego é a terra. Para Vicente Risco, a terra é como Deus, un ser adorado e sagrado. Este «sentimento relixioso da terra», como o chama o propio Risco, reúne a todos os galegos e «distingue á alma galega» (Risco, 2000, p. 17); ofrece unha característica da súa personalidade e da súa identidade colectiva. Este sentimento é a base dunha ética e dunha estética (Risco, 1920). Está vinculado coas orixes de Galicia e a «sobrevivencia indudabel d'unha emoción ancestral [...], a emoción sagrada dos primeiros abós celtas [...] y-esta emoción talmente se plasmou nas sus almas primitivas, qu'estas gardaron xa para sempre aquil deslumamento y-aquil amore qu'eles nos trasmitiron no sangue coma un heredamento espirtual que vive na lembranza escura da Raza» (Risco, 1920).

Así, alén dun sistema de produción de bens materiais, a paisaxe é tamén fonte de bens culturais. Para Castelao, o ruralismo de Galicia orixinou unha cultura nobre, europea e humana, o episodio dos Cancioneiros, sendo un dos máis famosos. A poesía galega é, segundo Castelao, «unha poesía ao ar libre, con paisaxes de infinida fremosura» (Castelao, 2000, p. 341). Para Manuel Murguía, un poeta galego tiña que inspirarse na paisaxe, o vínculo coa natureza é a especificidade da literatura galega (Fortes, 2000, p. 73). E Rosalía de Castro confirmouno no prólogo do seu libro Follas novas, «o poeta non pode prescindir do medio no que vive e da natureza que o rodea» (Fernández, 1983, p. 321), vinculando así os creadores co seu contorno, como nunha relación umbilical entre o home e o medio natural. Como o poeta, o artista -pintor ou escultor- tamén se nutre da paisaxe e dunha atmosfera galega específica buscada no clima, a luz e os elementos naturais. Desde o Romanticismo, o mesmo amor pola paisaxe está presente nos artistas galegos, como asegura o pintor Raimundo Patiño Mancebo (1936-1985) (1978, p. 478). En Arte e galeguismo, escrito en 1919, Castelao define as bases dunha arte nacionalista que sexa, asemade, universal. Fai mención a unha identidade colectiva vinculada á terra, xa que, segundo 
pensa, toda arte ten a súa patria. Manuel Murguía foi o primeiro en se referir á existencia dunha pintura galega, citando a importancia da cor, desde a época romántica. En opinión de Luís Seoane (1910-1979), pintor e crítico, a cor, as matizacións vinculan os artistas galegos cos dos demais países europeos do Atlántico norte. Unha serie de coincidencias probaría a existencia dunha expresión pictórica moi particular, caracterizada por unha forma singular, por un humor e mais un lirismo que «humanizan os elementos da natureza». Segundo este crítico, a pintura galega segue a corrente dunha pintura europea que, ao longo da costa atlántica, expón «unha liña romántica, non clásica, empeñándose en entender o misterio do home e da natureza» ${ }^{4}$. «Estas formas [...] mostran nos artistas galegos, unha observación da natureza e una unión con ela», explica Luís Seoane (Braxe e Seoane, 1996, p. 18). Esta actitude estaba inspirada na teoría do filósofo francés Hypolite Taine, que afirmaba que unha obra de arte era, ante todo, o produto da «raza» e do clima. Esta teoría determinista e naturalista vía a orixinalidade e o carácter innovador na identidade xeográfica 5 . Estévez Ortega, crítico respectado dos anos 20 e 30, falaba mesmo de "galicianía», é dicir, dun medio propicio a unha unidade pictórica ${ }^{6}$. Esta poética específica así como a relación coa paisaxe marcarán, segundo Antón Castro (1992, p. 45 e 141), unha posible identidade artística galega e definirán o que se chamará «a estética do granito», que Luís Seoane une, polas súas formas redondeadas, á arte celta (Seoane, 1979, p. 11). Segundo Seoane, a situación xeográfica galega, fronte ao océano, e a analoxía co conxunto dos países bañados polo Atlántico contribuíron a darlle forma á «estética do granito». Castelao, en Arte e galeguismo,

${ }^{4}$ Para os Noucentistas, o Mediterráneo forxa tamén un carácter peculiar e produce un tipo de sensibilidade artística. Segundo Antoni Gaudí: «os artistas mediterráneos sempre serán superiores aos nórdicos porque se dedican á observación da natureza».

${ }^{5}$ Di Taine: «Dúas fozas principais determinan os pensamentos e os actos dos homes: unha, a natureza, a outra, a cultura. Considerade alternativamente esas dúas forzas nas obras de arte que as fai visibles. Cada escola representou un temperamento, o temperamento do seu clima e do seu país» (cf. Guasch, 1985, p. 44).

${ }^{6}$ De aí a denominación desde aquela época dunha «Escola de pintura galega», aínda que o conxunto dos pintores rexionalistas está lonxe de constituír un corpo homoxéneo. Así mesmo, na escultura, os artistas van na procura dunha renovación plástica pola recuperación das formas tradicionais e a toma de conciencia da súa identidade cultural e espiritual. Máis tarde, o grupo dos Renovadores son, segundo Luís Seoane, os primeiros aos que se pode definir como os precursores dunha arte galega, cualificada por Seoane de "pintura da terra». O manifesto «Máis alá», de 1922, asinado polo poeta Manuel Antonio e o pintor Álvaro Cebreiro, tratou de romper co tópico costumista dos creadores galegos así como coa Xeración Nós, á que consideraron vinculada ao século XIX e ao pasado. 
explica estas coincidencias pola relación particular que ten cada galego coa natureza que soubo transformar nunha obra de arte chamada "paisaxe». Xa que logo, en cada galego agáchase un artista. O home fixo a paisaxe e esta fixo ao home e, aínda máis, a paisaxe fixo ao artista. Para Castelao, a paisaxe é o espello da creación do home e, asemade, esta imaxe devolta ao home nutre a súa creatividade. Así, Castelao aconséllalles aos artistas que copien os elementos, as formas, as materias da natureza para crear o seu propio estilo: «Nada de copear ornamentos gregos nin arquivoltas oxivais, somente a natureza» (Castro, 1992, p. 141). A arte, resume Castelao, é filla da paisaxe e do carácter do artista. Así, a paisaxe sería como o fío condutor cara á arte. O segredo dun verdadeiro artista é saber mirar a natureza e, sobre todo, entender a paisaxe para poder pintala: «Cómpre que os pintores coñezan Galicia para pintala. Cómpre que os galegos teñan no peito o sentimento da paisaxe para seren artistas» (Castro, 1992, p. 147). E precisa que "para pintar Galicia ten que sentirse, non doutra maneira se comprende que algúns pintores de sona, chegados de fóra declarasen impintables as paisaxes galegas. Son impintables para eles, mais non para nós. Son impintables para quen non comprende máis que o vermello, o azul e o amarelo; mais son pintables para quen está afeito a distinguir mil matices diferentes do verde, dende o case amarelo ata o case azul» (Castro, 1992, p. 150). Para Castelao, as cores xa marcan a diferenza con outras comunidades de España e proban a existencia dunha paisaxe diferente e, xa que logo, dunha identidade particular. A alteridade na creación artística galega empeza quizais pola cor.

Segundo Castelao, a saudade é a fonte principal de creación artística e poética: «Quen podería abolir a morriña dos galegos que viven fóra dos eidos nativos? Porque ese sentimento diferencial é fecundo para crear xeitos propios do ser e, polo tanto, da cultura» (Rodríguez Castelao, 2000, p. 218). A inspiración de Rosalía de Castro é, para Kathleen Kulp-Hill, a saudade ou tristeza producida pola ausencia, no tempo e no espazo, de seres e lugares amados. Esta nostalxia é a clave que lle dá acceso ao descubrimento dunha beleza ata o de agora perdida no cotián, e que se prolonga no tempo baixo a forma desta tristeza lancinante e fecunda chamada saudade.

A saudade, como espírito da paisaxe e forza da terra, interroga ao home, ás veces tortúrao, pero só para lle brindar unha riqueza espiritual que lle permita traspasar os límites da súa condición humana. Para Roberto Nóvoa Santos, 
médico e escritor (1885-1933) citado por Castelao, a saudade é unha enerxía da terra, que se lles transmite aos homes por medio de elementos misteriosos e interrogadores da paisaxe. E, para Castelao, un máis alá soñado, transcendido en realidade na súa propia terra: «A saudade [...] endexamais pode condurcirnos á desesperanza, porque coa ilusión do "máis alá" fuximos do mundo real e chegamos aos mundos ensoñados; podemos crear países de fadas, paradisos de felicidade, até confundir a nosa Terra co Ceo» (Rodríguez Castelao, 2000, p. 440). Esta saudade emerxe así do encontro entre o home e a paisaxe. Está, como o confirma Roberto Nóvoa Santos, «na íntima comunión do home coa paisaxe e na tendencia do home e revertirse á mesma terra que modelou a súa carne e a súa alma [...]. A visión da paisaxe crepuscular é o mellor estímulo da saudade [...]. A vontade de retornarmos aos eidos nativos cando estamos lonxe deles, intensifícase e culmina no "instinto da morte" que é forma suprema de reversión á terra» (Rodríguez Castelao, 2000, p. 438-439).

A saudade xorde coa ausencia ou o arredamento. Agora ben, a distancia ou, aínda peor, o exilio son vividos como unha aflición. No caso do exilio, a identidade persoal de todo individuo sofre unha inestabilidade ontolóxica, debida ao transplante xeográfico. Castelao, forzado ao exilio por razóns políticas durante e despois da Guerra Civil, rememora así os lugares aos que sente pertencer, nos que a súa vida individual se inscribe e se funde. Descríbeos no nome do grupo cuxa conciencia o absorbe naquel momento e esta dimensión colectiva envolve por completo as dimensións individual e persoal de Castelao ${ }^{7}$. No barco que bordea as costas mediterráneas, Castelao vive a experiencia da alteridade ${ }^{8}$, ao confrontar a paisaxe que divisa coa que rememora: «a presencia das costas meridionaes de Hespaña non son como para seducir a un patriota galego, porque nelas descobrimos a fisionomía dun estado moruno moi distante da nosa Patria» (Rodríguez Castelao, 2000, p. 547). Este confrontarse cos elementos da paisaxe

\footnotetext{
${ }^{7}$ Forma parte das modalidades da construción da identidade individual e da captación da alteridade. Os contornos familiar, social e colectivo son as diferentes fases da formación da identidade de cada individuo. $\mathrm{O}$ encontro entre estas tres fases participa da construción identitaria. No caso de crise grave, a identidade colectiva envolve as demais (Mucchielli, 2002, p 72-73).

${ }^{8} \mathrm{~A}$ «captación da alteridade» é propicia para «a construción dunha conciencia de pertenza colectiva». A chegada a «terras alleas, consecutiva ao exilio, vívese, en certa medida, como unha agresión que provoca un repregamento no seo do grupo", de xeito que está dividido entre observación e rememoración (Delrue, 2006).
} 
fai que se recolla no seu interior e se refuxie na evocación das paisaxes da súa terra. Noutro capítulo de Sempre en Galiza, Castelao describe unha estadía en Estremadura: oponlles á secura, á impresión de afogo e de desidia, os elementos da paisaxe galega, a «sombra fresca das carballeiras de Lalín», os «piñeiraes da beiramar de Noia», os «arumes mariñeiros de Bueu», o «cume do Montelouro», a «frescura do meu mar de Rianxo», a «fonte cantareira da Estrada», os «salseiros de Corrubedo», o «ar puro de Curtis», ou a "paz vizosa do Lérez»; e só diante destas evocacións se sente "fortalecido" (Rodríguez Castelao, 2000, p. 69).

O territorio galego é magnificado polo sufrimento. «Quen podería abolir a morriña dos galegos que viven fóra dos eidos nativos?» (Rodríguez Castelao, 2000, p. 91), pregunta Castelao. O exilio -ou o que se vive como tal- reaviva o cariño e exacerba a fermosura; a memoria é atormentada por formas, cores, lugares, obxectos que compoñen paisaxes, que se converten en seres vivos cuxa ausencia funde ao home nunha profunda nostalxia. Castelao, durante o seu exilio, espertou unha madrugada nun hotel de Marsella e sorprendeuse lembrando un discurso de Otero Pedrayo que cita de memoria: «Se no abrente deste día poidéramos voar sobor da nosa Terra e percorrela en todas direccións, asistiríamos á marabilla dunha mañán única. Dende as planuras de Lugo inzadas de bidueiros, até as rías de Pontevedra, oureladas de piñeiraes; dende as serras nutricias do Miño e a gorxa montañosa do Sil, até a ponte de Ourense, onde se peitean as augas de entrambos ríos; ou dende os cabos da costa brava da Cruña, onde o mar tece encaixes de Camariñas, até o curuto do monte de Santa Tegra, que vence coa súa sombra os montes de Portugal, por todas partes xurde unha alborada de groria» (Rodríguez Castelao, 2000, p. 520).

En Castelao, a paisaxe galega e o paraíso terrestre son un. Varias veces cualifica a paisaxe de Galicia de "paradiso», xa que os galegos «superaremos a predición relixiosa e trocarémola en Paradiso» (Rodríguez Castelao, 2000, p. 92). A paisaxe suscita en moitos autores esta comparación co paraíso, é, resume Raffaele Milani, «a memoria e a esperanza dunha alegría intemporal» (Milani, 2005, p. 140). En Castelao, os elementos da paisaxe anímanse e convocan cadanseu anaco de beleza e de ideal ao servizo do único territorio galego: «A arquitectura barroca do noso chan, labrada en pedra granítica, está sempre coberta por un manto de xugoso verdor. Os montes son redondos como peitos de muller e as serras son como lombos de boi cebado. Os vales son ledos e farturentos. O mar 
tolea de carraxe cando non o deixan penetrar na terra; pero cando entra, quédase adormecido no leito das rías» (Rodríguez Castelao, 2000, p. 90). Cada elemento simboliza a paisaxe e, para Castelao, a patria é a conxugación dos elementos típicos da paisaxe galega: «o carballo, o mar, o trigo, a noite estrelada ou a chuvia..." ${ }^{9}$, elementos que animan a paisaxe e "difunden a identidade», se empregamos a expresión de Anne Sgard.

O proceso identitario está a funcionar: a identidade engánchase a elementos pouco espectaculares, pero moi ben identificados e repetidos. Estes mesmos elementos opóñense ao que se pode atopar a outro lado da "fronteira». Xa que, como explica Raffaele Milani, a paisaxe precisa certa percepción dos límites e ten que estar circunscrita por un horizonte momentáneo ou duradeiro (Milani, 2005, p. 39-40). Agora ben, «unha paisaxe identitaria resúmese facilmente a través dun ou varios compoñentes ben recoñecibles aos que a paisaxe pode amarrarse; unha paisaxe uniforme, fuxitiva, na que non se desprende ningún elemento, dificilmente atopa un valor identitario», precisa Anne Sgard (1997). Castela, cunha paisaxe máis austera, confúndese nos escritos políticos ou poéticos co «deserto», palabra usada por Rosalía de Castro e tamén polo escritor, xornalista e político Antón Vilar Ponte (1881-1936) nunhas cartas enviadas ao poeta Teixeira de Pascoaes (1877-1952), para o que a paisaxe constituía unha inextinguible fonte de inspiración (Vilar Ponte, 1999, p. 59 e 131). Así, o deserto castelán e o fértil territorio de Galicia están separados por unha «fronteira». Trátase aquí dunha fronteira identitaria, o que significa, lembra Jackson, «o que se mantén xunto. $\mathrm{O}$ acento ponse tanto sobre o que separa como sobre o que vincula" (Jackson, 2003, 14-15). Agora ben, este país único é como unha pedra preciosa, protexido por «fronteiras naturais», que rodean unha unidade paisaxística ben identificada: para Castelao, só a rexión do Miño, cruzada por unha fronteira oficial, pero artificial, comparte unha mesma paisaxe, froito dunha única civilización: «Cando un galego entra nas planuras de León ou de Zamora, síntese en terra allea, invadido pola tristura que producen os desertos. Cando entra en Asturias ten que afacer os seus ollos a un novo estilo de paisaxe. Pero cando traspón a fronteira portuguesa, síntese na propia terra, e non dá creto ás arbitrariedades da política hestórica» (Castelao, 2000, p. 90).

\footnotetext{
${ }^{9}$ Véxase Rodríguez Castelao, «Homenaje al Consello de Galicia», Montevideo, 01/07/1945.
} 
Antón Vilar Ponte explica nun artigo da revista Nós que a influencia da paisaxe propiciou a creación de vínculos de amor entre Portugal e Galicia, separados por unha fronteira «absurda» (Vilar Ponte, 1921). O poeta Xavier Bóveda Pérez (1898-1963) fala dunha «alma galaico-lusitana», que comparte un mesmo «saudosismo» (Vilar Ponte, 1999, p. 51).

Castelao resume así a unicidade do territorio galego: «Galiza é unha unidade territorial harmónica, de formas e coor, perfeitamente diferenciada do resto da Hespaña» (Rodríguez Castelao, 2000, p. 90), un territorio español que el rexeita.

Así, cada elemento da paisaxe serve tanto para definir como para opoñerse. Ademais, cada un é non só marcador dunha identidade colectiva, senón tamén dunha identidade individual; Rosalía foi unha dos primeiros autores que sentiu a paisaxe como elemento central non só da identidade galega senón mesmo da súa propia identidade persoal. Segundo Michel Collot, «a procura ou a elección de paisaxes privilexiadas é unha forma buscarse a un mesmo» (Collot, 1995, p. 217-218). «O corpo da nai [explica este autor] define o primeiro espazo confiado á exploración da persoa [...]. Jean Guillaumin formulou a hipótese de que a paisaxe adulta conservaba esta marca maternal [...]. Esta hipótese está confirmada pola abundancia das metáforas de uso que, na descrición das paisaxes, remite á nai». O propio Vicente Risco, nun discurso panteísta ve a terra como unha «segunda placenta», xa que o noso corpo «é un anaco d'éla [...]: éla está en nós [...]. Éla está na nósa y-alma e no nóso entendimiento, que d’éla veñen, que d'éla son fillos, como o corpo o é. Éla enche d'imaxes o nóso interior, y-esí como alimenta ó corpo co-as especies físecas, tamén alimenta á y-alma co-as especies sensibles. Pertenecémoslle en corpo y-alma» (Risco, 1920). Raffaele Milani aborda o tema da protección materna baixo a «forma dunha totalidade envolvente e difusa, como unha flutuación ininterrompida de emocións e de datos perceptibles, unha irradiación afectiva» (Milani, 2005, p. 51). Para Michel Collot, o xardín é, sen dúbida ningunha, a metáfora do ventre materno. A poeta Rosalía de Castro, no prólogo de Cantares gallegos, fala de Galicia como dun "xardín no que se respiran aromas puros, frescura e poesía». Un lugar que se converte en verdadeiro xardín do Edén en Castelao: «Vexo [...] unha Terra farturenta, onde todos traballan e viven en paz. Vexo a miña Terra como unha soia cibdade, a cibdade-xardín máis fermosa do mundo, a cibdade ideal para os homes que queiran vivir a carón da Natureza» (Rodríguez Castelao, 2000, p. 
189). Agora ben, o xardín, explica Michel Collot, é «o lugar pechado e secreto cos seus misterios no que estamos» (Collot, 1995, p. 277). Ten ese lado interior, íntimo, lugar ideal da construción da súa propia identidade persoal. Antón Vilar Ponte, citando ao poeta portugués Teixeira de Pascoaes, expón nun artigo da revista Nós o papel central da paisaxe na existencia do home, xa que a alma da paisaxe lle transmite as súas calidades á alma humana. Así, unha paisaxe pode influír positiva ou negativamente. Cita dous exemplos: a Rexión do Miño, que presenta unha paisaxe alegre, e a de Trás-os-Montes, que, cunha paisaxe dolorosa, rexistra máis crimes (Vilar Ponte, 1921). Tamén o confirma o poeta e dramaturgo Xavier Bóveda Pérez nunha carta mandada ao seu colega portugués: segundo Bóveda, a alma galega é un "produto» da paisaxe (Vilar Ponte, 1999, p. 51). Así, a paisaxe galega marca aos homes ata revelalos e revelar neles formas e caracteres do seu ser que non sospeitaban. A paisaxe é un elemento que esculpe ao individuo galego.

A paisaxe identitaria desempeña, así, dúas funcións: unha, de cohesión interna, que é a que nos interesa, e outra función externa de produción dunha imaxe destinada á mirada exterior, explica Anne Sgard. Pero precisa, «o discurso sobre a paisaxe é un discurso eminentemente cultural. Manexa o vocabulario estético, presenta unha mirada distanciada e comparativa, expresa esa percepción de maneira analítica, argumentada» (Sgard, 1997). É un discurso cultural, pero tamén ideolóxico e político, mesmo nos poemas de Rosalía de Castro. «O lado político cobre o posto máis ancho e agresivo», explica Ricardo Navas Ruiz, no seu comentario do poema "Castellanos de Castilla»; céntrase en dúas cuestións: a dureza de corazón dos casteláns e a fealdade da paisaxe de Castela, en comparación coa galega. E Ricardo Navas Ruiz pregunta, sen contestar, se se pode falar de conciencia separatista, xa que a representación da paisaxe, expresión dun ideal de beleza e de organización, revela ser o vehículo privilexiado dun ideal político, que se manifestaría no recoñecemento dunha Nación galega. Segundo Castelao, a patria atopa as súas orixes e o seu carácter na terra: a terra nai alberga «unha moitedume infinida de luciñas, que son os seres innominados que ninguén recorda xa, e que xuntos forman o substractum insobornable da nosa patria» (Rodríguez Castelao, 2000, p. 519). Vicente Risco, evocando o amor innato dos galegos pola terra, chega a falar de "patriotismo vexetal» (Risco, 1920). 
Agora ben, para Castelao, «a Patria é a Terra», pero, cando describe esta Terra, convértea en álbum de paisaxes: «A Terra, que cría frores nos campos para regalía dos ollos e albres para que canten os paxaros; onde atopamos sombra fresca no vran e quentura garimosa no inverno[...]; onde o vendaval brúa nas ponlas dos carballos e funga nas cordas dos barcos; onde canta o vento nos piñeiras[...]; onde por primeira vez ollamos a choiva, a brétema, o sol, o luar, o arco da vella e a noite estrelecida» (Castelao, 2000, p. 92).

En Vicente Risco, a Terra, máis que as paisaxes, é signo da existencia dunha única e soa etnia. En efecto, para Risco, o factor terra é a condición da nacionalidade ${ }^{10}$, que separa «as nacionalidades nómadas das nacionalidades sedentarias [...]. Falamos eiquí de pobos sedentarios, de pobos civilizados, de pobos europeos. Ora, en Europa, unha nacionalidade é un pobo afincado n-unha terra» (Risco, 2000, p. 17). E a nación, para Vicente Risco, é «unha comunidade d'intreses espirtuaes e materiaes detreminada pol-a natureza» (Risco, 2000, p. 18).

A Terra implica a pertenza e o enraizamento. A etnia é o froito da Terra; a paisaxe, pola súa banda, depende do home. É obxecto e suxeito, obxectivo e subxectivo. Lugar da infancia e do íntimo, é o crisol en que se funda a identidade persoal, xa que é o lugar do cotián, obxecto dun vaivén constante entre o home e mais a natureza. Pegada histórica, marca social e patrimonio cultural, a paisaxe é tamén unha das representacións da identidade colectiva, xa que é, coma ela, plural, complexa, aberta ás influencias e evolucións. A paisaxe é, na teoría nacionalista galega, a condición sine qua non que constrúe o home, o pobo e o artista. A Terra, pola súa parte, é, nos discursos nacionalistas, unicamente étnica. De aí o nacemento das teorías racistas vinculadas á etnicidade suposta dos homes que comparten unha mesma Terra. En Vicente Risco, a paisaxe é un dato, unha doazón da natureza. Como conclusión do seu ensaio Teoría do nacionalismo galego propón dúas medidas para protexela; a primeira é a construción de «miradores pr'os turistas nos vales mais pintorescos da nosa Terra, coma ningunha rica en paisaxes fermosos» (Risco, 2000, p. 43); a segunda forma parte dunha demanda máis global: a de "proclamar a soberanía estética da Nazón Galega» e

${ }^{10}$ Do mesmo xeito, o teórico nacionalista catalán Enric Prat de la Riba situaba a terra como o primeiro dos elementos que constitúe a nacionalidade (Prat de la Riba, 1988, p. 89). 
que se exercerá netamente na "espropiación de moimentos e paisaxes» (Risco, 2000, p. 39). Desafortunadamente, Risco non dá máis detalles sobre estes proxectos de nacionalización dos lugares estimados como os máis fermosos do territorio. Estas propostas levan o selo dunha paisaxe intocable e sagrada, cando en Castelao é o resultado dun intercambio constante e sempre respectuoso entre o home e a natureza. A paisaxe é cultural en Castelao, e étnica en Risco. Este matiz de aproximación marca, sen dúbida ningunha, unha diferenza ideolóxica entre os dous. En Castelao, a teoría da paisaxe está fundada esencialmente no seu carácter «insulario», é dicir, na súa impermeabilidade con respecto a un contorno hostil e ameazante; convértese así na expresión sublimada dun ideal estético e dunha vontade política. 


\section{BIBLIOGRAFÍA}

BERTRAND, G.: «Le paysage entre la Nature et la Société», en A. Roger (dir.): La théorie du paysage en France (1974-1994), Seyssel, Ed. Champ Vallon, 1995.

Bourgeors, B.: «L'idéalisme allemand devant la beauté naturelle et l'embellissement de la nature», en F. Dagognet (dir.): Mort du paysage? Philosophie et esthétique du paysage, Seyssel, Ed. Champ Vallon, 1982, pp. 161-181.

BraXe, L. e X. Seoane: Luís Seoane. Textos sobre arte, Santiago de Compostela, Consello da Cultura Galega, 1996.

Castro, A.: Arte y nacionalismo. La vanguardia histórica gallega (1925-1936), Sada (A Coruña), 1992.

COLlignON, B.: «Les fondements territoriaux de l'identité inuit hier et aujourd'hui», en J. BONNEMAISON, L. Cambrezy e L. Quinty-Bourgeois: Les territoire de lidentité. Le territoire, lien ou frontière?, t. I, Paris, L'Harmattan, 1999.

Collot, M.: «Points de vue sur la perception des paysages», en A. ROGER (dir.): La théorie du paysage en France (1974-1994), Seyssel, Ed. Champ Vallon, 1995.

Dagognet, F. (dir.), Mort du paysage? Philosophie et esthétique du paysage, Seyssel, Ed. Champ Vallon, 1982.

DelRUe, E.: «Repercuciones de exilio/desexilios en la conciencia colectiva y/o individual: algunos libros de viaje de Vicente Blasco Ibañez», en Exilio y desexilio en el mundo hispánico contemporáneo. Los caminos de la identidad. Actas del Congreso, Universidad de Gijón, Hispanística, 2006.

Díaz Santana, B.: Os celtas en Galicia, A Coruña, Editorial Toxosoutos, 2002.

FERnÁndez, X. R.: Historia contemporánea de Galicia, A Coruña, Gamma, 1983.

ForTes, B.: Manuel Murguía e a cultura galega, Santiago de Compostela, Ed. Sotelo Blanco, 2000.

Guasch, A. M.: Arte e ideología en el País Vasco: 1940-1980, Madrid, Akal, 1985.

JACKSON, J. B.: A la découverte du paysage vernaculaire, 2003. [Biblioteca Nueva prepara unha edición en castelán].

MilANI, R.: Esthétique du paysage, 2005. [Hai edición en castelán: El arte del paisaje, Madrid, Biblioteca Nueva, 2007].

Mucchielli, A.: Lidentité, Paris, PUF, 2002.

PatiÑo MANCebo, R.: «La expresión artística», en Galicia, realidad económica y conflicto social, A Coruña, Banco de Bilbao, 1978.

PRAT DE LA RibA, E.: La nacionalidad catalana, Madrid, Biblioteca Nueva, 1988.

RisCO, V.: «O sentimento da terra na raza galega», Nós, n. ${ }^{\circ}$ 1, Ourense, 30 outono, 1920.

Risco, V.: Teoría do nacionalismo galego, Santiago de Compostela, Sotelo Blanco, 2000.

Rodríguez Castelao, A. D.: Sempre en Galiza, Vigo, Editorial Galaxia, 2000.

SEOANE, L.: Textos encol da arte galega, Madrid, Brais Pinto, 1979.

SGARD, A.: «Paysages du Vercors: entre mémoire et identité», Revue de Géographie Alpine, Université Joseph Fourier, novembro, 1997.

Vilar Ponte, A.: «Da paisaxe e a pintura», Nós, n. ${ }^{\circ} 4,1921$.

Vilar Ponte, A.: Os intelectuais galegos e Teixeira de Pascoaes. Epistolário, Ediciós do Castro, 1999. 